\title{
Profile of Off-task Behavior in Primary School Students
}

\author{
Ipah Saripah ${ }^{\bowtie 1}$ \& Haning Tri Widiastuti² \\ 1,2 Educational Psychology and Counselling, Universitas Pendidikan Indonesia, Bandung, Indonesia \\ $\triangle$ ipah_bk@upi.edu
}

\begin{abstract}
As an effort to achieve the developmental tasks of primary school age children, they are expected to obtain the basics of knowledge that are considered important to successfully adapt to adult life, and learn various important skills. However, there were several aspects that inhibit the achievement of the developmental tasks, for instance, off-task behavior, in which students disengaged from the learning environment by performing unrelated behavior. The occurrence of off-task behavior phenomena in primary school students needs to be addressed. Therefore, this research aims at investigating the profile of off-task behavior in primary school students. This quantitative research was conducted using the instruments of off-task behavior. This research involved 25 fifth grade primary school students in one private primary school in South Jakarta. The research results revealed that there were $60 \%$ of the students who were categorized performing moderate rate of off-task behavior with motoric aspect was the highest rare (38.7\%).
\end{abstract}

Keywords: developmental tasks, motoric aspect, off-task behavior, primary school, students

How to Cite: Saripah, I., \& Widiastuti, H. T. (2019). Profile of Off-task Behavior in Primary School Students. Mimbar Sekolah Dasar, 6(2), 174-184. doi:10.17509/mimbar-sd.v6i2.17571.

INTRODUCTION Primary school is the first level of formal education as a form of education for students. At this level, children are expected to obtain the basics of knowledge that are considered important to successfully adapt to adult life, and learn various important skills (Hurlock, 1980, pg. 146). At that time, children as students have begun to have responsibilities to learn and do assignments. They also have some learning developmental tasks needed to be achieved. According to Hurlock (1980), the developmental tasks consist of learning physical skills; developing healthy attitude; learning to be adapted to peers; starting to develop the appropriate social roles for men and women; developing the basic skills, such as reading, writing and calculating; developing viewpoints required for everyday life; developing conscience, moral sense, and value system and level; developing attitudes towards social groups; and achieving privacy.

The developmental tasks that can be achieved properly are expected by all teachers, parents and students themselves. Nevertheless, there are some obstacles encountered by the students in order to achieve the developmental tasks. The obstacles include lack of students' motivation, inappropriate allocation of time, lack of suitability in terms of learning curriculum with its development, less conducive class conditions, and the 
Ipah Saripah \& Haning Tri Widiastuti, Profile Off-Task Behaviour...

existence of disruptive behavior (off-task behavior).

Off-task behavior is one of students' learning behaviors indicated by doing activities that are unrelated to learning, in which the students completely lose control in the learning environment and tasks (Baker, 2007). Rathov (as cited in PateClevenger et al., 2008) explains that offtask behavior is all activities carried out by students outside the given task. Based on these opinions, off-task behavior is defined as students' disengagement from the learning environment that leads to unrelated behavior

Donetta and Kulinna (2007) state that there are three forms of unexpected behavior occurred in the classroom, namely off-task behavior, aggressive behavior and non-participant behavior. These unexpected behaviors required action when occurring during lesson hours, since the students would not engage in the learning environment. The students who perform off-task behavior would disrupt the learning process in the classroom.

Marchan and Martella (as cited in Martinez and Brock, 2009) explain that, every day, the students performed only $4 \%$ of on-task behavior, in meaning that the students performed off-task behavior in the remaining time (96\%). Baker (2007) predicts that the amount of time of students' offtask behavior was about $15 \%-25 \%$ of teaching time. The previous research showed that off-task behavior occurred in every different class and level. The emergence of off-task behavior in almost every education level is considered as reasonable behavior. In this research, most students performed off-task behavior in the moderate rate $(60 \%)$, while the remainder of students performed off-task behavior in the low rate $(24 \%)$, and in the high rate (16\%).

In fact, off-task behaviors occurred in almost every education level. The research conducted by Riyadi (2015) to 36 students in one of senior secondary school in Subah, Batang, Central Java showed that during learning hours, there were the students who liked to make noise, and chat with friends (8\%), students who made fun with friends (22\%), students who did not focus on teachers' explanation (53\%), and students who liked to sing in the classroom (28\%). The research conducted by Sukiman (2011) to primary school students in one elementary school in Kudus Regency showed that the off-task behavior occurred in mathematics learning was $42.2 \%$

Off-task behavior occurs in various forms. Rathvon (as cited in Pate-Clevenger et al., 2008) explains that off-task behavior is considered as verbal (excessive talking), physical, and interrupted behaviors that are impolite. This statement is emphasized by Pate-Clevenger et al. (2008) in which off-task behavior comprises talking without permission, doing activities without permission, behaving aggressively, 
daydreaming, not paying attention to teachers, and playing with things or persons. Nowadays, these various conditions become the educators' common concerns. Various forms of offtask behavior are classified into four aspects, namely verbal, motoric, solitary, and inactivity aspects. This classification is based on the opinions expressed by Baker (2007) and Shapiro (2011). According to Baker (2007), off-task behavior consists of off-task conversation, off-task solitary behavior, and inactivity.

Karweit and Slavin (1981, as cited in Baker, 2007), state that primary school students used $10-50 \%$ of their time on off-task behavior in regular class. It indicates that the amount of learning time wasted by students who performed off-task behavior could reach most of the learning time, which should not be ignored by the teachers. In primary school students, offtask behavior stably occurs in secondgrade to fourth-grade, and it decreases in fifth-grade (Martinez and Brock, 2009). Third-grade was chosen because it is a transition class from low-grade to highgrade, hence, the transition of learning methods is required for them.

Based on the previous research conducted to 25 third-grade students in one of private primary schools in South Jakarta, they performed different off-task behavior. Students' off-task behavior includes running around the class, disturbing friends, talking out of the learning material, drawing, daydreaming, chatting to friends in class, and playing in class during learning hours.

Off-task behavior tends to be considered as reasonable behavior along with its emergence in almost every class and level. However, basically, off-task behavior disrupts and inhibits the learning process. In general, off-task behavior has a negative effect on the learning process (Sabourin et al., 2011). This behavior reduces the time of instruction, and makes the students become more difficult to succeed academically (Luiselli et al. in Kraemer et al., 2012).

The disadvantages obtained by students due to off-task behavior include lack of understanding in learning material, which can lead to a decrease in academic grade, loss of the study time, less liked by friends due to annoying behavior, often getting a reprimand by teachers, having a bad record at school, and low learning achievement. This issue signifies that the students should immediately be given an intervention to be able to reduce this behavior. If the intervention is not carried out, this off-task behavior tends to deteriorate, and has a serious risk of problems throughout life (Meany-Wallen et al., 2015). Based on the aforementioned statements, the changes in students' behavior in learning must be early conducted since primary school.

There are several reasons regarding the forms of off-task behavior performed by the participants. Dreikers, Grunwald and 
Ipah Saripah \& Haning Tri Widiastuti, Profile Off-Task Behaviour...

Pepper (as cited in Blvestein, 2013) state that off-task behavior is experienced by students because they intend to get the recognition and acceptance as desired. In other words, students who with bad behavior want to get attention. In line with Bluestein (2013), students who perform offtask behavior often intend to get attention. There are different causes of students in seeking attention. In addition, Muijs and David (2008) claim that home conditions, family background and differences in values implemented at home are considered as the influential factors on students' behavior in class. Furthermore, they also explain that students from the unstable family background tend to be more disruptive at school.

The factor of students' lack of attention at home is similar to the condition of the most third-grade students in A-class in one of private primary schools in South Jakarta. Based on the results of data collected from the students through interviews with classroom teachers, it was revealed that almost all parents of students in the A-class had jobs. This condition requires the students to be cared for by other family members, e.g. grandparents or household assistants. In terms of time, the students only had time to interact with their parents in the morning before going to school, and in the afternoon or evening when their parents came home from work. Moreover, since their parents still had to take care of the housework, the quality of their interactions with parents sometimes became poor. This pattern of interaction made students got less attention, and eventually, they sought attention in the classroom by themselves, hence, off-task behavior emerged.

Other factor that triggered the occurrence of the participants' off-task behavior was caused by family upbringing. The students who were not cared for by their parents would obtain freedom, and lose control, especially for those cared for by household assistant. This happened because household assistant did not dare to scold students for reasons of fear of being complained and fired, so that the students got privileged at home and freedom to do everything as desired, and wanted the same conditions in school. The students with permissive parenting eventually acted on their desires in classroom (off-task behavior) and ignored the teachers' reprimands.

Another reason of students to behave offtrack is their lack of understanding of difficult learning materials and tasks (Armbruster, 2011). This statement is supported by Moor and Sweeney (as cited in Pate-Clevenger et al., 2008), stating that difficult tasks will affect off-task behavior.

According to Baker, Cocea and Hershkovitz (2009), off-task behavior is related to poor learning.. Moreover, poor learning can be caused by poor classroom management, so that it affects the occurrence of off-task behavior in 
classroom. Emmer and Gerwels (as cited in Pate-Clevenger et al., 2008) explain that poor classroom management has an impact on students' off-task behavior. Relating to classroom management, Sun and Shek (2012) state that poor behavior in classroom emerges, if the teachers are not sufficient authoritative to control the classroom learning situation. The occurrence of off-task behavior in classroom tends to have a negative effect that leads to new problems for teachers and students.

According to Karweit and Slavin (1981, as cited in Baker, 2007), students' inattention is considered the biggest factor that makes the loss of teaching time. Greenwood et al. (as cited in Martinez and Brock, 2009) state that children with the high rate of off-task behavior cannot respond to learning, or manage quickly and accurately. Based on these experts' opinions, off-task behavior has a negative effect on the students, especially for the continuity of students' academic achievement, although the majority of the participants did not have a problem on academic achievement.

Based on the aforementioned explanation, this research seeks to focus on the effort to provide the empirical of the profile of primary school students' offtask behavior. This research is considered important because there are limited research on off-task behavior carried out at primary school level. Furthermore, the research result can be utilized for the development and optimization of appropriate learning method in primary schools.

\section{METHOD}

This research employs a quantitative approach with a descriptive method, and it was conducted in 2017/2018 Academic Year. This research involved 25 third-grade students, and two teachers selected based on the school's recommendation and the research needs.

This research was conducted in three stages: namely preparation stage, main stage, and final stage. In the preparation stage, preliminary study and problem identification was carried out. Next, in the main stage, the process of collecting data was done using questionnaires and observations and data processing. In the final stage, the process of drawing conclusion was carried out to answer the research questions.

The instrument in the forms of questionnaires designed for obtaining data on students' off-task behavior. The instrument contained forms of students' offtask behavior based on verbal, motoric, solitary, and inactivity aspects.

\section{RESULTS}

Based on the data processing, the most forms of off-task behaviors performed by the students were doing the other subject assignments in classrooms; scribbling on table/paper/book when feeling bored; wiggling the chair; cheating on friends' 
Ipah Saripah \& Haning Tri Widiastuti, Profile Off-Task Behaviour...

homework; and eating in the classroom during lesson hours. Furthermore, the frequency distribution of their off-task behavior is presented in Table 1.

Table 1. General Frequency Distribution of Off-Task Behavior.

\begin{tabular}{llll}
\hline Rate & $\begin{array}{l}\text { Score } \\
\text { Range }\end{array}$ & f & $\begin{array}{l}\text { Percentage } \\
\text { (\%) }\end{array}$ \\
\hline High & $\geq 9$ & 4 & 16 \\
Moderate & $4-9$ & 15 & 60 \\
Low & $<4$ & 6 & 24 \\
\hline Total & & 25 & 100 \\
\hline
\end{tabular}

Table 1 depicts that 15 students (60\%) performed moderate rate of off-task behavior, and six students (24\%) performed low rate of off-task behavior, and four students (16\%) performed high rate of offtask behavior.

The performed off-task behavior based on its aspects is presented in Graph 1.

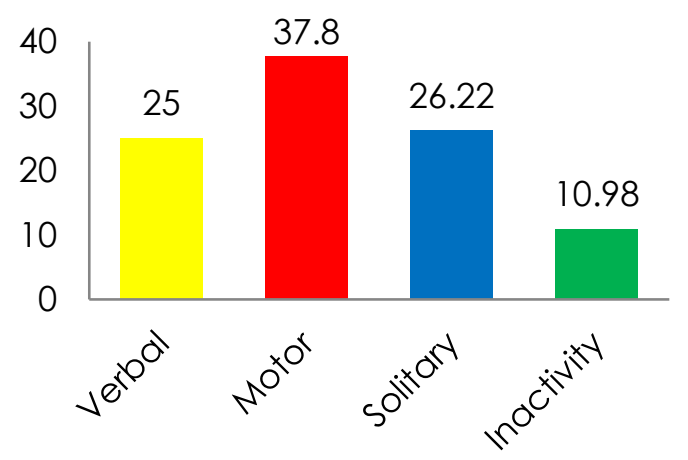

Graph 1. Description of Students' Off-Task Behaviour based on Its Aspects.

The highest rate of off-task behavior in motoric aspect (37.8\%), in solitary aspect $(26 \%)$, and in verbal aspect (25\%). Meanwhile, the lowest rate of off-task behavior occurred in inactivity aspect (10.9\%)

The results of data processing were divided off-task behavior into three categories: high, moderate and low rates, depicted in the following Graph 2.

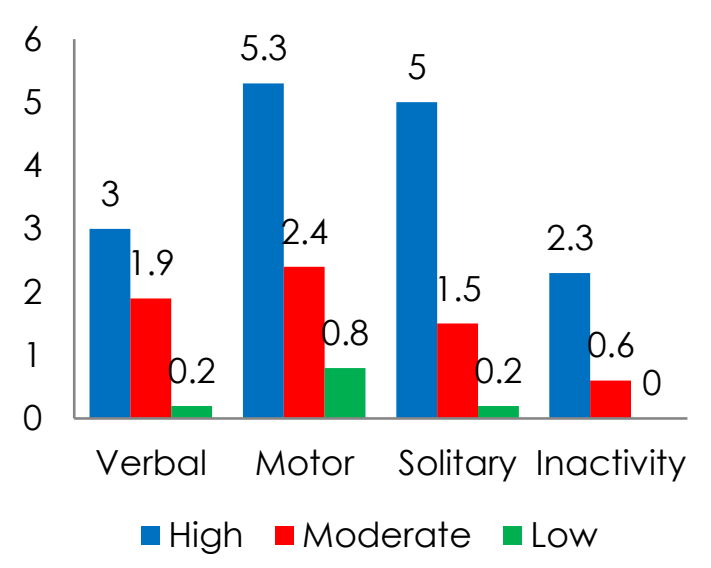

Graph 2. Average Score of Off-Task Behavior in Each Category.

\section{DISCUSSION}

The research results revealed that the majority of participants' off-task behavior conditions were in the moderate rate $(60 \%)$, then in the low rate $(24 \%)$, and in the high rate (16\%). Based on its aspects, the highest rate of off-task behavior performed by the third-grade students in A-class in one of private primary schools in South Jakarta was in the motoric aspects, indicated by the frequent forms of behaviors, such as tapping a pencil or pen on the floor/table.

The tendency of the motoric aspect as the most frequent off-task behavior aspect occurred by primary school students is logical because at that period, they really 
do dynamic movement and physical activities more (Hurlock, 1980). In line with this statement, the research conducted by Godwina et al. (2016) confirmed that offtask behavior was found more in the male students (who tended to do physical activities more) compared to the female students.

Off-task behavior had a negative effect on the students' development, especially in the learning process. In addition, the effect of off-task behavior was also perceived by the teachers. According to Sayeski and Brown (as cited in Prior, 2014), the teachers who lost their teaching time were able to suffer from stress, and to feel that they are unable to teach. This opinion was supported by Sun \& Shek (2013) discovering that the students' bad habits could not be tolerated, because it made the teachers suffer from stress. Moreover, off-task behavior also had a negative effect on the relationship between the teachers and the students, because this behavior broke the values of respect, harmony and conformity in the relationship between the students and the teachers in the classroom. The conditions were similar to the conditions experienced by the thirdgrade teachers in A-class in one of the private primary schools in South Jakarta. They claimed that they suffered stress and confusion in dealing with students' off-task behavior.

Off-task behavior was required to be addressed, because without intervention, the students with off-task behavior would tend to deteriorate, and had a serious risk of problems throughout life (Meany-Wallen et al., 2015). This statement showed that if off-task behavior were not immediately addressed, it would affect other problems for the students. Fleming et al. (in Blvestein, 2013) explained that if the intervention was successful in reducing naughty and antisocial behavior in the students in primary school and junior high school, they had the opportunity to achieve academic success in senior high school.

The majority of the experts agreed that offtask behavior was forms of behavior that disrupted the learning process. Nevertheless, Killian and Hofer (2013) provided a slightly different perspective on off-task behavior. Instead of classifying it as a form of improper behavior, off-task behavior was reconstructed as a manifestation of various student motivations in the classroom. The students' value orientation emerged as the strongest predictor of off-behavior, and it was mediated between parental monitoring and motivational monitoring. Furthermore, the research recommended the importance of the role of the teacher in helping the students reconcile their many values and goals in the classroom.

The negative effect and problems caused by off-task behavior initiated the experts in conducting the research to find efforts in reducing off-task behavior. The research conducted by Wicks (2012) to pre-school students intended to reduce students' offtask behavior using picture activity 
Ipah Saripah \& Haning Tri Widiastuti, Profile Off-Task Behaviour...

schedule, the research results revealed that picture activity schedule was able to reduce the students' off-task behavior by $45 \%$, which was started from $65 \%$ to $20 \%$.

The research conducted by Meany-Wallen et al., (2014) used Adlerian Play Therapy to 58 primary school students. The research results revealed that Adlerian Play Therapy was able to reduce behavioral problems significantly. At the same level, Bradley (2014) conducted the research to the primary school students in Montesore in attempting to reduce off-task behavioral by providing the learning using three strategies: behavioral learning, social learning and cognitive learning. Based on the research results, the behavioral learning strategies became the most influential intervention in reducing the students' off-task behavior.

Austin, Soeda and Riley (2008?) used fixed time schedule in reducing the off-task behavior of two third-grade students with a fixed time range of four minutes, the results revealed that fixed time schedule was proven effective to reduce off-task behavior.

Furthermore, Moore (2013) conducted the research to three children with an age range of 12-13 years who performed high level of off-task behavior using selfmanagement as the intervention method. The results revealed that self-management was able to reduce the students' off-task behavior, and the increase of on-task behavior was up to $50 \%$.
In line with the self-management approach, individual behavioral interventions were also proven effective for addressing off-task behavior. Based on the research conducted by Honda and Sasaki (2008), the research results revealed that episodes of disruptive behavior (such as leaving chair selfishly, fighting, making noise, and behaving badly to others) significantly decreased after conducting the individual behavioral interventions session.

Bradley (2014) expressed that the most successful intervention in reducing off-task behavior was behavioral learning theory. The students experienced the highest decrease in off-track behavior when they were given direct responsibility for being aware, and changing their own behavior that was not related to the previous learning process. The results showed that they were able to share knowledge to support their community learning.

Better classroom management by the teachers was also considered to be able to reduce the students' off-task behavior, because effective classroom management was able to maximize the students' learning opportunity (Charles, 2002; Everston, Emmer \& Worsham, 2003, as cited in Santrock, 2008). In addition, effective classroom management aims at helping the students to spend more time learning and reduce activities that are not goal-oriented, and preventing students from experiencing academic and emotional problems (Santrock, 2008). 
Even though, there were various approaches from the previous explanations that had been proven effective, off-task behavior did not only become the teachers' responsibility at school, but also the parents' responsibility at home. Therefore, the teachers and the parents are expected to collaborate in addressing the students' off-task behavior.

\section{CONCLUSION}

The research results revealed that the students who were categorized in the moderate rate of off-task behavior with the motoric aspect that was considered as the highest rate occurred in the students.

Off-task behavior was occurred due to feeling bored, monotonous learning, less friendly classroom, difficult or easy learning, and lack of family attention to children.

Off-task behavior must be addressed, because it could decrease the students' academic achievement. There are various methods that can be used to reduce offtask behavior, e.g., picture activity schedule, play therapy, fixed time schedule, and better classroom management.

For further researchers who are interested in conducting similar research, it is recommended to add factors that affect off-task behavior, such as the teachers' teaching methods, or parenting methods. In addition, the increasing number of samples is also needed for obtaining more representative results that can be generalized.

\section{REFERENCES}

Armbruster. (2011). Issue: Off-Task Behavior. University of Pittsburgh.

Austin, J. L., \& Soeda, J. M. (2008). Fixedtime teacher attention to decrease off-task behaviors of typicallydeveloping third graders. Journal of Applied Behavior Analysis, 41, 279-283.

Baker, R. (2007). Classroom Activities and Off-Task Behavior in Elementary School Children. [Online]. Retrieved on 22 March 2016from http://www.columbia.edu/ rsb2162/G odwinetal_v12.pdf

Baker, R. (2007). Modeling and Understanding Students' Off-Task Behavior in Intelligent Tutoring Systems. $\mathrm{CHI}$.

Baker, R. (2009). Differences between Intelligent Tutor Lessons, and the Choice to Go Off-Task. Educational Data Mining, pp 11-26.

Baker, R., Cocea M. \& Hershkovitz, A. (2009). The Impact of Off-Task and Gaming Behaviors on Learning Immediate or Aggregate. Proceedings of the 2009 Conference on Artificial Intelligence in Education: Building Learning Systems That Care: From Knowledge Representation to Affective Modelling. Amsterdam: IOS Press, pp. 507-514. 
Ipah Saripah \& Haning Tri Widiastuti, Profile Off-Task Behaviour...

Blvestein, J. (2013). Manajemen Kelas (translated by Siti Mahyuni). Jakarta: PT Indeks.

Bradley, C. (2014). Decreasing Off-Task Behaviors in an Elementary Classroom. Thesis (published). Masters of Arts in Education Action Research. St. Catherine University.

Elizabeth H. 1980. Psikologi Perkembangan Suatu Pendekatan Sepanjang Rentang Kehidupan. Jakarta: Erlangga.

Godwina, K., Almedab, M., Seltmanc, H., Kaib, S., Skerbetzd, M., Bakerb, R. \& Fisher, A. (2016). Off-task Behavior in Elementary School Children. Journal of Learning and Instruction, 44. 128-143. http://dx.doi.org/10.1016/jlearninstruc. 2016.04.003.

Honda, Y. \& Kazuyoshi, S. (2018). Effects of Individual Behavioral Intervention on Student's Off Task Behavior. The Japanese Journal of Educational

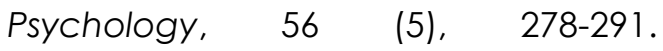
http://doi.org/10.5926/jiep 1953.56.2_278.

Kilian, B. \& Hofer, M. (2013). Conflicts Between On-Task \& Off-Task Behavior in the Classroom; The Influences of Parental Monitoring, Peer Value Orientation, Student's Goal, and Their Value Orientation. Journal of Social Psychology of Education, 16 (1). 77-94. http://doi.org/10.10007/s1121 18-0129198-y.
Kraemer, E., Davies, S., Arndt, K. \& Hunley, S. (2012). A Comparison of the Mystery Motivator and The Get 'Em On Task Interventions for Off-Task Behaviors. Psychology in the Schools, 49 (2), pp. 163- 175.

Martinez, E. \& Brock, S. (2009). Time OnTask. [Online]. Retrieved on 10 April 2016 from http://www.education.com/referemc e/article/time-on-task/

Meany-Walen, K., Kottman, T., Bullis, Q. \& Taylor, D. (2014). Effects of Adlerian Play Therapy on Children's Externalizing Behavior. Journal of Counseling \& Development, 93, pp 418- 428.

Meany-Walen, K., Kottman, T., Bullis, Q. \& Taylor, D. (2015). Group Adlerian Play Therapy with Children with Off-task Behaviors. The Journal for Specialist in Group

Moore, D., Anderson, A., Glassenbury, M., Lang, R. \& Didden, R. (2013). Increasing On-Task Behavior in Students in A Regular Classroom: Effectiveness of A Self-Management Procedure Using A Tactile Prompt. Journal Behavior Education, 22, pp. 302-311.

Muijs, D. \& David, R. (2008). Efective Teaching. Yogya: Pustaka Pelajar.

Pate-Clevenger, R., Dusing, J., Houck, P. \& Zuber, J. (2008). Improvement of OffTask Behavior of Elementary and High School Students Through the Use of 
Cooperative Learning Strategies. Chicago. Master of Arts in Teaching and Leadership.

Prior, J. (2014). Love, Engagement, Support and Concistency: A Recipe for Classroom Management. Chilhood Education, pp. 68-70.

Riley, J., McKevitt, B., Shriver, M. \& Allen, K. (2011). Increasing On-Task Behavior Using Teacher Attention Delivered on A Fixed-Time Schedule. Journal Behavior Education, 20, pp. 149-162.

Sabourin, J., Rowe, J., Mott, B., \& Lester, J. (2011). When Off-Task Is On-Task: The Affective Role of Off-Task Behavior In Narrative-Centered Learning Environments. Artificial Intelligence In Education, 6738, pp. 534-536.

Santrock, J. (2008). Psikologi Pendidikan Edisi Kedua (diterjemahkan oleh Tri Wibowo). Jakarta: Kencana.

Shapiro, E. (2011). Academic Skills Problems Direct Assessment and Intervention. New York \& London: The Guilford Press.

Sun, R. \& Shek, D. (2012). Classroom Misbehavior in The Eyes of Students: A Qualitatif Study. The Scientific World Journal.

Sun, R. \& Shek, D. (2013). Student Classroom Miebehavior: An Exploratory Study Based on Teachers' Perceptions. Journal Child Health Humanity Development, 6(1), pp. 4958.
Wicks, C. (2012). Increasing On-Task Behavior in a Pre-School Student with a Developmental Delay Using a Picture Activity Schedule. Special Education Journal, 10(2). 